\title{
Analysis on the Performance of a Prototype of Thermoelectric based Power Generation System
}

\author{
Ali Elghool ${ }^{1}$, M. F. Naeem ${ }^{1}$, Firdaus Basrawi1 ${ }^{1, ~ *}$, Hassan Ibrahim $^{1}$, DMND Idris ${ }^{1}$, Khairul \\ Habib $^{2}$ and Mohd Hazwan Yusof ${ }^{1}$ \\ ${ }^{1}$ Energy Sustainability Focus Group, Faculty of Mechanical Engineering, Universiti, Malaysia \\ Pahang, Pekan, Pahang, Malaysia. \\ ${ }^{2}$ Department of Mechanical Engineering, University Technology Petronas, 32610, Tronoh, Perak'.
}

\begin{abstract}
There are needs on electricity but people cannot get electricity including when doing outdoor activities at isolated areas, selling goods in night market and during disaster such as flood and earthquake. People need electricity especially for charging communication gadgets and lighting. Thus, the objective of this study is to develope and test the performance of a small prototype of thermoelectric generator (TEG) based power generation system. The TEG based power generation system developed consists of heat collector, thermoelectric generator, heat pipe and fin based heat sink, and DC-DC converter. The heat collector was designed to ensure the suitable temperature for the TEG which is should not exceed $320^{\circ} \mathrm{C}$ on the hot side. Heat pipes was used to increase the power output by lowering or maintaining the temperature at cold side, to ensure large temperature difference is obtained. The prototype was tested and data of temperature, voltage and current were collected. A cell phone was used during the test as a load to the system. All the data were recorded by using temperature data recorder, power meter and multimeter. It was found that the highest maximum power output was 7.7 watt at the temperature difference of $138^{\circ} \mathrm{C}$. The output is sufficient to charge the cell phone and it is also possible to light an LED bulb. However, it did not achieve the maximum output of $43 \mathrm{~W}$. This is a results of limitation of maximum electrical load (only one cell phone was used) and the limitation of the performance of the prototype. Thus, although the prototype is succesfully generate enough power to charge a cell phone, but improvement in heat sink design, and adding more electrical load are needed to get better results.
\end{abstract}

\section{Introduction}

Globally, approximately 1.4 billion people lack on the access to electricity with the vast majority of those people living in rural areas. Furthermore, the number of people depending on the traditional use of biomass is projected to reach 2.8 billion by 2030 [1]. In Malaysia, the coverage of electricity still does not reach the whole population [2]. Besides that there are circumstances that electricity is needed, but people cannot get electricity including when doing outdoor activities at isolated areas, selling goods in night market and during disaster

\footnotetext{
*Corresponding author: mfirdausb@ump.edu.my
} 
such as flood and earthquake. People need electricity especially for charging communication gadgets and lighting.

In a small scale, the waste heat from any source including charcoal, wood, LPG, and candle can be directly converted to electrical power through a semiconductor device such as thermoelectric that works on the basis of Seebeck effect. Commercial thermoelectric generator (TEG) are usually made of Bismuth Telluride (Bi2Te3) with series junction, where one junction with two dissimilar metal. TEG is divided to two sides, cold side and hot side. The difference in temperature of these two sides creates a potential difference, and as a result electricity is generated. The rate of electricity generation is based on the temperature difference of hot side and cold side of TEG [3-5].

Thermoelectric generators have recently been investigated as a method of electricity generation with biomass as heat source. The use of TEG for waste heat to electricity conversion is not new, but perhaps is only now becoming more important in everyday applications [6]. For instance, Codecasa et al. [7, 8] recently developed a $5 \mathrm{~W}, 12 \mathrm{~V}$ TEG system with the goal of powering an autonomous gas heater for commercial outdoor use. Many of the research carried out are more on the potential of TEGs utilize heat from cooking stoves. Some studies focused on optimizing the TEG output under fixed parameters [9]. This method does offer valuable information on the performance of the generator [6]. Killander and Bass [9] are among pioneer in experimentally investigated TEG integration into a cooking stove. In their study in an isolated home in northern Sweden, a TEG was connected to a wood-fed stove, and by using two TEG modules, their prototype was capable of producing up to $10 \mathrm{~W}$. Champier et al. $[10,11]$ investigated on the potetial of using TEG to utilize exhaust gases heat from an energy efficient mud cooking stove. An experimental rig was setup initially using a $2.2 \mathrm{~kW}$ butane gas burner. By using four TEGs, $10.5 \mathrm{~W}$ was achieved. The authors obtained between $1.7 \mathrm{~W}$ and $2.3 \mathrm{~W}$ per module at an approximate module temperature difference of $160^{\circ} \mathrm{C}$.

In this paper, the main focus is to develope and test a prototype of thermoelectric based power generator. The aim is to generate $43 \mathrm{~W}$ of power by a proper design of the system, especially on heat sink side in which heat pipe and fins was used.

\section{Materials and methodology}

\subsection{Types of source}

As long as heat is supplied, thermoelectric can be used to generate electricity. Heat source can be liquid petroleum gas (LPG), charcoal, wood, candle and other biomass. In the first place, it is important to understand the characteristics of temperature from different heat source. This is because TEG needs the highest temperature possible to get large temperature difference, but it must not exceed its survival temperature which is approximately $300{ }^{\circ} \mathrm{C}$. Thus, flame temperature of these options of heat source was investigated using a thermocouple under open burning condition.

It was found that the flame temperature of charcoal, wood, LPG and candle under open burning condition were approximately $900-1050{ }^{\circ} \mathrm{C}, 745-905{ }^{\circ} \mathrm{C}, 810-950{ }^{\circ} \mathrm{C}$, and $795-860$ ${ }^{\circ} \mathrm{C}$. Thus, the range of temperature for common heat source for TEG is $745-1050{ }^{\circ} \mathrm{C}$. This temperature is beyond the maximum temperature that can be accepted for the TEG. Thus, apart from material consideration, dimension of heat collector plays important role in achieving the appropriate temperature to be applied to the hot side of TEG. 


\subsection{Description of the proposed system}

Fig. 1 shows the design of the prototype. A heat collecter is at the bottom and attached to the hot side of the TEG. Then, heat is transfered to the cold cold side of the TEG. It should be noted that 2 TEGs were used and they were connected in series to get higher voltage. The cold side was attached to extender, and some portion of heat pipes were inserted in the aluminium extender. TEGs did not need any thermal paste as it is built with graphite foil as thermal interface material. On the other side of heat pipes, there are fins to dissipate heat to environment. Each TEG has 3 heat pipes, and 11 aluminium fins to dissipate heat. The dimension of each fin is $85 \times 100 \mathrm{~mm}$. Epoxy glue was used to attached heat pipes to the extender and fins.

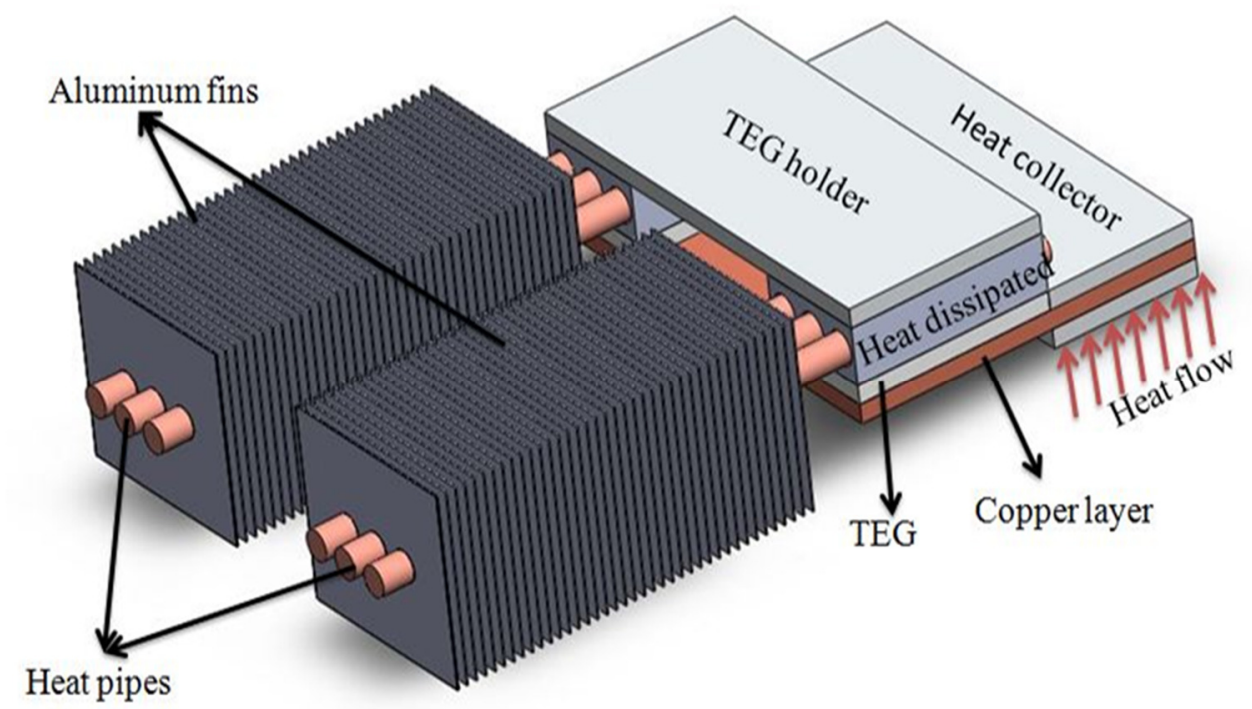

Fig. 1. A schematic of the combined heat pipe-thermoelectric generator, heat sink and collector.

Table 1 describes the TEG specifications. When hot side is supplied with $300{ }^{\circ} \mathrm{C}$ of heat, whereas cold side is maintained at $30^{\circ} \mathrm{C}$, the TEG has the capability to generate $7.2 \mathrm{~V}, 3.0$ amps, and consequently generates $21.6 \mathrm{~W}$. Table 2 describes the parameters of the heat pipes that were used in this study. The heat pipes have fibre wick structure with heat flux of $50 \mathrm{~W}$. Thus, $300 \mathrm{~W}$ of heat can be transfered through 6 heat pipes used. 
Table 1. Thermoelectric Specifications.

\begin{tabular}{|c|c|c|c|c|c|}
\hline $\begin{array}{c}\text { Maximum Hot } \\
\text { side } \\
\text { temperature } \\
\left({ }^{\mathbf{0}} \mathbf{C}\right)\end{array}$ & $\begin{array}{c}\text { Maximum cold } \\
\text { side temperature } \\
\left({ }^{\mathbf{0}} \mathbf{C}\right)\end{array}$ & $\begin{array}{c}\text { Dimensions } \\
\mathbf{m m}\end{array}$ & $\begin{array}{c}\text { Voltage } \\
(\mathbf{V})\end{array}$ & $\begin{array}{c}\text { Current } \\
(\mathbf{A})\end{array}$ & $\begin{array}{c}\text { Power } \\
(\mathbf{W})\end{array}$ \\
\hline 320 & 180 & $56 \times 56 \times 4.45$ & 7.2 & 3.0 & 21.6 \\
\hline
\end{tabular}

Table 2. Heat pipe parameters

\begin{tabular}{|l|l|}
\hline Outer diameter & $6 \mathrm{~mm}$ \\
\hline Wall thickness & $0.2 \mathrm{~mm}$ \\
\hline Length & $200 \mathrm{~mm}$ \\
\hline Heat Flux (W) & $50 \mathrm{~W}$ \\
\hline Material of wick & Copper \\
\hline Wick structure & Copper fibre wick \\
\hline Material of pipe & Copper \\
\hline
\end{tabular}

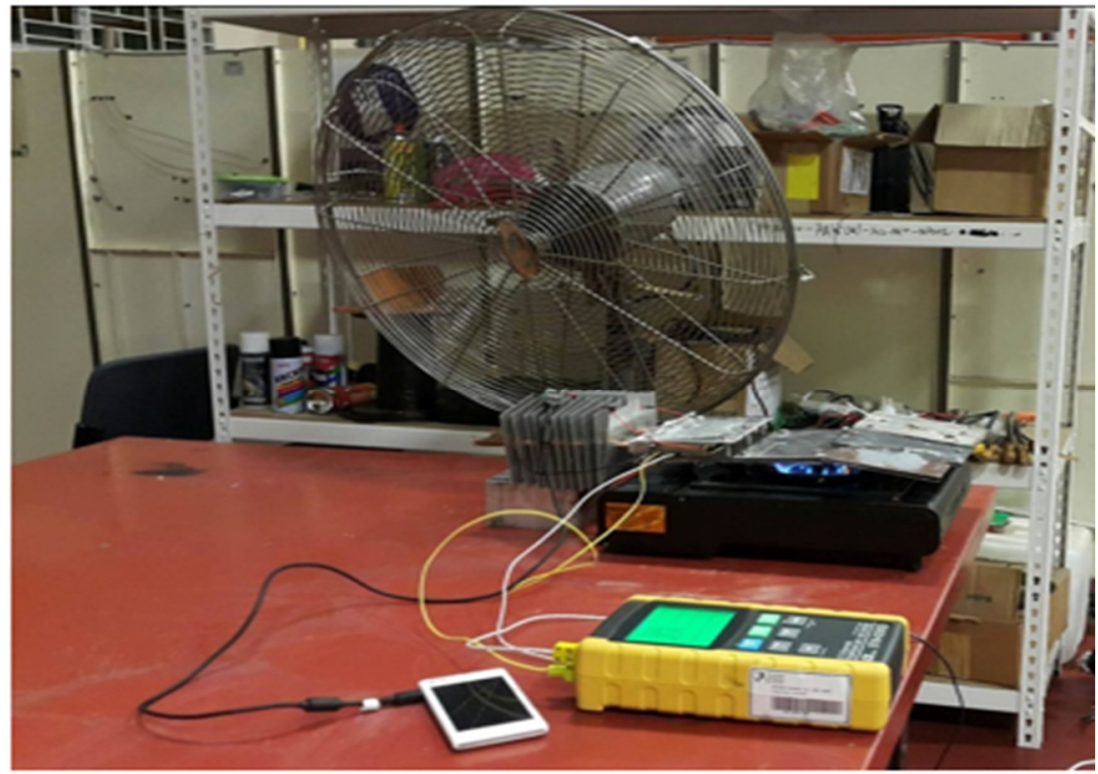

Fig. 2. The experimental setup of the system.

\subsection{Testing and Data Collection}

Testing of the protorype was carried out as shown in Fig. 2. LPG fired cooking stove was used as the heat source and a cell phone was connected as electrical load. The data collected were temperature, voltage and current. For temperature, 12 Channels Temperature Recorder, BTM-4208SD was used. Thermocouples were placed at hot side and cold side of TEG. It was recorded with interval of 60 seconds for 1420 seconds (approximately 23 minutes). For the voltage, it can be taken for open circuit and close circuit. But for the current, the circuit has to be loaded so the current can be measured. For this test, the DC-DC converter was connected to the TEG because device like cell phone has their limit in receiving the voltage, commonly $5.0 \mathrm{~V}$. From the voltage and current measured, power $P[\mathrm{~W}]$ can be obtained by common equation as shown below. where $I$ is current [amps], and $V$ is voltage [Volt]. 


$$
P=I V,
$$

In order to increase the heat dissipation, the fins were cooled down by using forced convection, with the flow rates of air through a fan.

\section{Results and discussion}

The results are shown in Fig. 3. Fig. 3(A) shows temperature difference between hot-cold side of the TEG. It can be seen that the temperature difference increased constantly until 1000 $\mathrm{s}$, then the temperature was almost constant which indicates that the operation have reached its steady-state. It was found that the highest temperature difference was $138{ }^{\circ} \mathrm{C}$, and this is around half of the maximum temperature that can be applied to TEG which is $270^{\circ} \mathrm{C}$.

Fig. 3(B) and 4(C) shows results for Voltage and Current output, respectively. As shown in the figures, current and voltage show similar trend with temperature difference. The maximum voltage was $11 \mathrm{~V}$, and current was $0.7 \mathrm{~A}$. The maximum power obtained was 7.7 $\mathrm{W}$ as shown in Fig. 3(D). The cell phone condition also shown a charging is on-going during the testing process. Although the phone charging condition was successfully achieved, the maximum power output of $7.7 \mathrm{~W}$ is less than what was expected, which is $43 \mathrm{~W}$ as per design of 2 TEGs. This is a results of limitation of maximum electrical load (only one phone was used) and the limitation of the performance of the prototype. For the electrical load problem, higher load should be applied for the future testing.

For low temperature difference, the main cause was perhaps due to lack of heat sink design because it was observed that the temperature at heat fins side also almost reached 100 ${ }^{\circ} \mathrm{C}$ during the end of testing. Thus, improvement in heat sink is needed for better power output.

It can be concluded that although the prototype is succesfully generate enough power to charge a phone, but improvement in heat sink design, and adding more electrical load are needed to get better results.
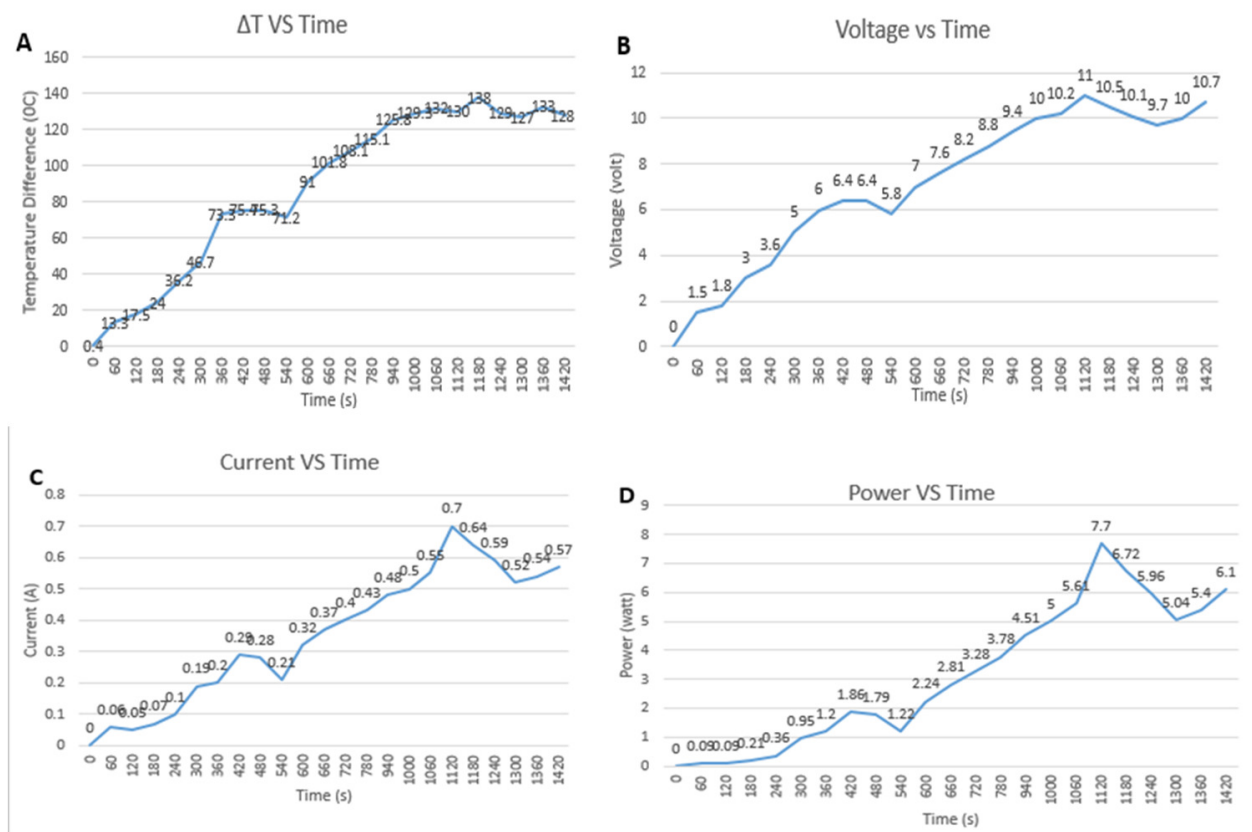

Fig. 3. Chart for temperature difference vs time (A), voltage vs time (B), current vs time (A) and power vs time (B). 


\section{Conclusion}

A prototype of thermoelectric generator (TEG) based power generation system was developed and tested. It consists of a heat collector, 2 TEGs connected in series, an extender, and heat pipe heat sink. It was found that the highest temperature difference was $138{ }^{\circ} \mathrm{C}$, maximum voltage was $11 \mathrm{~V}$, maximum current was $0.7 \mathrm{~A}$. and maximum power obtained was $7.7 \mathrm{~W}$. Although phone charging was successfully achieved, the maximum power output of $7.7 \mathrm{~W}$ is less than what was expected, which is $43 \mathrm{~W}$. This is a results of limitation of maximum electrical load (only one phone was used) and the limitation of the performance of the prototype. Thus, although the prototype is succesfully generate enough power to charge a phone, improvement in heat sink design, and adding more electrical load are needed to get better results.

\section{References}

1. N. Tanaka, O. Kjorven, and K. K. Yumkella, Energy Poverty: How to Make Modern Energy Access Universal? (OECD/IEA, 2010).

2. H. Borhanazad, S. Mekhilef, R. Saidur, and G. Boroumandjazi, Renew. Energy 59, pp. 210-219 (2013).

3. M. Hamid Elsheikh, D. A. Shnawah, M. F. M. Sabri, S. B. M. Said, M. Haji Hassan, M. B. Ali Bashir, and M. Mohamad, Renew. Sustain. Energy Rev. 30, pp. 337-355 (2014).

4. H. B. Gao, G. H. Huang, H. J. Li, Z. G. Qu, and Y. J. Zhang, Appl. Therm. Eng. 96, pp. 297-310 (2016).

5. X. F. Zheng, C. X. Liu, Y. Y. Yan, and Q. Wang, Renew. Sustain. Energy Rev. 32, pp. 486-503 (2014).

6. S. M. O’Shaughnessy, M. J. Deasy, J. V. Doyle, and A. J. Robinson, Appl. Energy 156, pp. 566-576 (2015).

7. M. P. Codecasa, C. Fanciulli, R. Gaddi, F. Gomez-Paz, and F. Passaretti, J. Electron. Mater. 42(7), pp. 2243-2248 (2013).

8. M. P. Codecasa, C. Fanciulli, R. Gaddi, and F. Passaretti, Design and Development of a Thermoelectric Cogeneration Device Integrated in Autonomous Gas Heaters, in AIP Conf. Proceedings-American Inst. Phys. pp. 512-515 (2012).

9. G. F. Rinalde, L. E. Juanicó, E. Taglialavore, S. Gortari, and M. G. Molina, Int. J. Hydrogen Energy 35(11), pp. 5818-5822 (2010).

10. D. Champier, J. P. Bédécarrats, T. Kousksou, M. Rivaletto, F. Strub, and P. Pignolet, Energy 36(3), pp. 1518-1526 (2011).

11. D. Champier, J. P. Bedecarrats, M. Rivaletto, and F. Strub, Energy 35(2), pp. 935942 (2010). 